\title{
PENGARUH MODEL PEMBELAJARAN PROBLEM BASED LEARNING (PBL) TERHADAP SIKAP ILMIAH DAN HASIL BELAJAR PESERTA DIDIK PADA SUB MATERI PSIKOTROPIKA
}

\author{
Yulia Rosdiana \\ Email: yuliarosdiana52@gmail.com
}

\begin{abstract}
Abstrak
Penelitian ini bertujuan untuk mengetahui adanya pengaruh model pembelajaran problem based learning terhadap sikap ilmiah dan hasil belajar peserta didik pada sub materi psikotropika di kelas XI MIPA SMA Tasikmalaya. Penelitian ini dilaksanakan pada bulan September 2018 sampai dengan bulan Juli 2019. Metode penelitian yang digunakan adalah quasy experiment. Populasi dalam penelitian ini adalah seluruh kelas XI sebanyak 5 kelas dan sampel yang digunakan sebanyak 2 kelas diambil dengan menggunakan teknik purposive sampling. Instrumen yang digunakan adalah non tes sikap ilmiah berupa angket dengan 16 pernyataan dan tes hasil belajar berupa soal pilihan majemuk sebanyak 33 soal. Teknik pengolahan dan analisis data menggunakan uji ANCOVA (Analysis of Covariance). Hasil penelitian menunjukkan bahwa PBL memiliki pengaruh signifikan terhadap sikap ilmiah siswa dengan ukuran efek 0,470 yang sedang. PBL juga memiliki pengaruh signifikan dan efek sedang terhadap hasil belajar, ukuran efeknya adalah 0,331 .
\end{abstract}

Kata kunci: problem based learning, sikap ilmiah, hasil belajar, psikotropika.

\begin{abstract}
Abstrak
This study aims to determine the effect of problem based learning model students' scientific attitudes and learning aoutcomes on psychotropic sub-material in Tasikmalaya High School XI MIPA class. This research was conducted in September 2018 until July 2019. The research method used was quasy experiment. The population in this study consist of 5 classes XI MIPA Class and the sample used as many as 2 classes was taken using purposive sampling technique. Data of students' scientific attitudes collected through questionnaire which consist of 16 statements and data of students' learning outcomes collected through 33 number of multiple choices test. Data processing and analysis techniques use the ANCOVA (Analysis of Covariance) test. The result showed that PBL has a significance influence to students' scientific attitudes with effect size 0.470 which is moderate. PBL also has significance influence and moderate effect to leaning outcomes, the effect size is 0,331 .
\end{abstract}

Keyword: problem based learning, scientific attitudes, learning outcomes, psychotropic.

\section{PENDAHULUAN}

Pendidikan merupakan salah satu usaha dalam meningkatkan kualitas dan potensi yang dimiliki oleh setiap individu. Melalui adanya pendidikan diharapkan dapat menciptakan sumber daya manusia yang memiliki kecakapan, kecermatan serta pengetahuan yang luas. Berbagai upaya untuk meningkatkan kuliatas pendidikan di Indonesia telah dilakukan, seperti peningkatan kualitas pengajar, peningkatan sarana dan prasarana yang mendukung serta pengembangan kurikulum.

Pengembangan kurikulum di Indonesia dimulai dari tahun 1947 hingga kurikulum terbaru yaitu kurikulum 2013 dan bahkan telah di lakukan perbaikan-perbaikan menjadi Kurikulum 2013 edisi revisi. Penerapan kurikulum 2013 memunculkan perubahan paradigma dalam pembelajaran, proses kegiatan pembelajarannya bukan berpusat pada guru (teacher centered) melainkan proses pembelajarannya harus berpusat pada peserta didik ( $s t$ udent centered). Pendekatan yang digunakan dalam penerapan kurikulum 2013 harus menggunakan pendekatan saintifik atau pendekatan ilmiah, pendekatan saintifik ini perlu dilakukan karena akan melatih peserta didik terlibat secara aktif dalam proses membangun pengetahuan, keterampilan dan sikap peserta didik. Dengan adanya proses pembelajaran yang berpusat pada peserta didik maka peserta didik dapat mengeksplorasi keterampilan proses yang akan mendorong peserta didik untuk menemukan fakta-fakta melalui serangkaian metode ilmiah yang dibangun atas dasar sikap il- 
miah sehingga nantinya diharapkan akan menghasilkan produk yang ilmiah.

Sikap ilmiah merupakan sikap yang harus ada pada diri seorang ilmuan ketika menghadapi persoalan-persoalan ilmiah (Anwar, Herson, 2009:111). Aspek sikap ilmiah seperti jujur, rasa ingin tahu, terbuka, skeptis, kerja sama dan kritis pada hakikatnya sudah dimiliki oleh peserta didik. Namun kadang-kadang sikap ilmiah tersebut tidak muncul dan tidak disadari oleh peserta didik. Padahal sikap ilmiah ini sangat penting untuk ditingkatkandalam diri peserta didik untuk membantu pengembangan sikap dan nilai positif serta menyeimbangi hasil belajar peserta didik. sejalan dengan pendapat Asnaeni, et.al., (2017:3) yang menjelaskan bahwa bahwa model pembelajaran problem based learning merupakan salah satu model yang dapat meningkatkan sikap ilmiah peserta didik, karena dengan kekhasan model ini yang ditandai dengan adanya masalah otentik dapat membuat peserta didik berpikir bebas yang dikemukakan dalam bentuk laporan dan akan dijadikan bahan evaluasi sehingga membantu peserta didik menjadi disiplin dan mengembangkan sikap penemuannya melalui kerja ilmiah yang pada akhirnya membudayakan sikap ilmiah.

Selain sikap ilmiah, keberhasilan pencapain konsep materi pun harus di dilihat. Untuk dapat melihat keberhasilan pencapaian materi di lihat dari hasil belajar peserta didik. Hasil belajar ialah kemampuan yang diperoleh peserta didik setelah melalui proses kegiatan belajar. Karena belajar itu sendiri merupakan suatu proses dari seseorang yang berusaha untuk mendapatkan suatu perubahan nilai yang positif. Sejalan dengan pendapat Nadjamudin, Lukman et, al., (2017:11) yang menjelaskan bahwa model pembelajaran problem based learning sangat berpotensi untuk meningkatkan hasil belajar peserta didik, karena model pembelajaran problem based learning memiliki kelebihan yakni peserta didik akan lebih memahami konsep yang diajarkan karena ia menemukan konsep dan pengetahuan sendiri sehingga pembelajaran menjadi lebih bermakna.

Berdasarkan hasil studi awal yang telah dilakukan di SMA Negeri 7 Tasikmalaya menunjukkan bahwa keinginan belajar peserta didik khususnya dalam mata pelajaran biologi masih rendah yang ditunjukkan dengan kurangnya rasa ingin tahu pe- serta didik terhadap materi pelajaran, sikap peserta didik yang masih cenderung pasif dalam mencari informasi ketika proses pembelajaran berlangsung, serta rendahnya antusiasme peserta didik dalam kegiatan diskusi. Dengan adanya permasalahan-permasalahan tersebut ditakutkan nantinya akan dapat mempengaruhi hasil belajar peserta didik. Di samping itu, di lihat dari nilai rata-rata hasil ulangan peserta didik pada materi psikotropika tahun ajaran 2017/2018 adalah 72, sedangkan batas minimal yang harus di capai adalah 76. Melihat kenyataan tersebut, perlu adanya upaya untuk meningkatkan sikap ilmiah dan hasil belajar peserta didik diantaranya dengan menggunakan model pembelajaran yang dapat menjadikan peserta didik terlibat aktif ketika dalam proses pembelajaran berlangsung yaitu dengan model pembelajaran problem based learning.

Barrows, Howard dan Hmelo-Silver (2006:24) menyatakan "Model pembelajaran problem based learning merupakan model pembelajaran aktif yang didasarkan pada penggunaan masalah yang tidak terstruktur sebagai stimulus untuk pembelajaran". Proses pembelajaran dengan menggunakan model pembelajaran problem based learning nantinya pembelajaran akan dimulai dengan pemberian masalah, peserta didik belajar berkelompok dan berperan aktif dalam proses merumuskan masalah, mengidentifikasi, mempelajari dan mencari sendiri materi yang terkait dengan masalah serta melaporkan solusi dari masalah. Dengan kegiatan pembelajaran seperti ini, maka peserta didik akan menerapkan metode ilmiah yang nantinya akan mengembangkan sikap ilmiah dan hasil belajar peserta didik.

\section{METODE PENELITIAN}

Penelitian dilaksanakan di kelas XI MIPA SMA Negeri 7 Tasikmalaya semster kedua tahun ajaran 2018/2019. Kegiatan penelitian dilaksanakan pada tanggal 22 April 2019 s.d 24 April 2019.

Metode yang digunakan dalam penelitian ini adalah metode quasy experiment. Penelitian ini dilakukan dengan memberikan perlakuan kepada kelas eksperimen dan menyediakan kelas kontrol sebagai pembanding. Penetapan jenis penelitian quasy experiment ini dengan alasan bahwa situasi kelas sebagai tempat pengkondisian perlakuan tidak memungkinkan pengontrolan yang demikian ketat 
sebagai mana yang dikehendaki dalam penelitian berjenis murni.

Desain penelitian yang digunakan dalam penelitian ini adalah Nonequivalent Pretest-Posttets Control Group Design. Peneliti memberikan pretest terlebih dahulu kepada peserta didik sebelum dilakukan pembelajaran dan memberikan posttest setelah dilakukan kegiatan pembelajaran. Dengan demikian, kemajuan dapat diketahui, karena peneliti membandingkan hasil sebelum dan setelah dilakukan pembelajaran.

Dalam penelitian ini yang menjadi variabel terikat adalah sikap ilmiah dan hasil belajar peserta didik di kelas XI MIPA SMA Negeri 7 Tasikmalaya pada sub materi psikotropika, sedangkan variabel bebas dalam penelitian ini adalah model pembelajaran problem based learning.

Populasi dalam penelitian ini adalah seluruh peserta didik kelas XI MIPA SMA Negeri 7 Tasikmalaya tahun ajaran 2018/2019 sebanyak 5 kelas. Sampel yang digunakan dalam penelitian ini sebanyak 2 kelas yang diambil secara teknik purposive sampling yaitu kelas MIPA 2 sebagai kelas kontrol yang pembelajarannya menggunakan model pembelajaran discovery learning dan kelas MIPA 3 sebagai kelas eksperimen yang pembelajarannya menggunakan model pembelajaran problem based learning. Instumen penelitian yang digunakan dalam penelitian ini adalah teknik nontes dan tes. Teknik non tes digunakan untuk mengukur sikap ilmiah peserta didik. Pengukuran sikap ilmiah dalam penelitian ini menggunakan angket yang terdiri dari 18 pernyataan, jawaban dari setiap pernyataan sudah disiapkan sehingga responden tinggal memilih, sedangkan teknik tes digunakan untuk mengetahui dan mengukur hasil belajar peserta didik. Tes hasil belajar yang digunakan pada penelitian ini adalah tes tertulis dalam bentuk multiple choice dengan 5 options sebanyak 50 soal.

Uji validitas tiap butir soal menggunakan program Anates versi 4.0.5 for windowsi. Berdasarkan hasil analisis butir soal dengan menggunakan program Anates versi 4.0.5 for windows, untuk instrumen penelitian sikap ilmiah diperoleh 18 pernyataan soal yang memenuhi kriteria valid dan 6 butir pernyataan yang tidak memenuhi kriteria valid, dan diperoleh reliabilitas soal sebesar 0,79 yang berarti bahwa angket yang diberika memiliki tingkat reliabilitas tinggi. Sedangkan untuk instrumen penelitian hasil belajar diperoleh 33 butir soal yang memenuhi kriteria valid dan 17 butir soal yang tidak memenuhi kriteria valid dan diperoleh reliabilitas sebesar 0,81 yang berarti bahwa tes hasil belajar yang diberikan memiliki tingkat reliabilitas yang tinggi.

Data penelitian di analisis dengan menggunakan uji prasyarat dan uji hipotesis. Uji prasyarat yang meliputi uji normalitas menggunakan uji kolmogorof smirnof dan uji homogenitas dengan menggunakan uji levene's. Kemudian dilanjutkan dengan uji hipotesis menggunakan uji ANCOVA (Analysis of Covariance) dengan bantuan aplikasi SPSS versi 23 for windows.

\section{III.Hasil dan Pembahasan}

\section{Data Hasil Penelitian}

Data penelitian diperoleh dari hasil pretest dan posttest sikap ilmiah dan hasil belajar di kelas kontrol dan kelas eksperimen. Adapun keseluruhan data dapat dilihat sebagai berikut.

Tabel 1. Statistik Sikap Ilmiah dan Hasil Belajar Peserta Didik di Kelas Eksperimen dan Kelas Kontrol

\begin{tabular}{|c|c|c|c|c|c|c|c|c|}
\hline \multirow[b]{2}{*}{ Statistik } & \multicolumn{4}{|c|}{ Eksperimen } & \multicolumn{4}{|c|}{ Kontrol } \\
\hline & $\begin{array}{c}\text { Pretest } \\
\text { Sikap } \\
\text { ilmiah }\end{array}$ & $\begin{array}{c}\text { Posttest } \\
\text { Sikap } \\
\text { Ilmiah }\end{array}$ & $\begin{array}{c}\text { Pretest } \\
\text { Hasil } \\
\text { Belajar }\end{array}$ & $\begin{array}{c}\text { Posttest } \\
\text { Hasil } \\
\text { Belajar }\end{array}$ & $\begin{array}{c}\text { Pretest } \\
\text { Sikap } \\
\text { ilmiah }\end{array}$ & $\begin{array}{c}\text { Posttest } \\
\text { Sikap } \\
\text { Ilmiah }\end{array}$ & $\begin{array}{c}\text { Pretest } \\
\text { Hasil } \\
\text { Belajar }\end{array}$ & $\begin{array}{c}\text { Posttest } \\
\text { Hasil } \\
\text { Belajar }\end{array}$ \\
\hline Skor Minimum & 49 & 67 & 10 & 20 & 46 & 60 & 7 & 14 \\
\hline Skor Maksimum & 68 & 82 & 21 & 30 & 68 & 80 & 18 & 27 \\
\hline Rentang & 19 & 15 & 11 & 10 & 22 & 20 & 11 & 13 \\
\hline Rata-Rata & 59,39 & 75,47 & 16,42 & 25,27 & 57,39 & 68,81 & 12,58 & 19,69 \\
\hline Varians & 22,36 & 15,91 & 7,68 & 5,35 & 38,87 & 27,87 & 7,39 & 7,7 \\
\hline Standar Deviasi & 4,73 & 3,99 & 2,77 & 2,31 & 6,23 & 5,28 & 2,72 & 2,78 \\
\hline
\end{tabular}


Tabel 1 menunjukan bahwa nilai rata-rata pretest sikap ilmiahdi kelas eksperimen memiliki skor sebesar 59,39 dan posttestnya 75,47, untuk nilai rata-rata pretest hasil belajar di kelas eksperimen yaitu sebesar 16,42 dan posttestnya sebesar 25,27. Selanjutnya nilai rata-rata pretest sikap ilmiah di kelas kontrol memiliki skor sebesar 57,39 dan posttestnya 68,81 , sedangkan untuk nilai rata-rata pretest hasil belajar di kelas kontrol yaitu sebesar 12,58 dan posttestnya 19,69.

Untuk pengujuan hipotesis yaitu dengan menggunakan uji ANCOVA (Analysis of covariance). Hasil dari uji ANCOVA dapat dilihat pada tabel 2 dan tabel 3.

Tabel 2 Ringkasan Hasil Uji ANCOVA Sikap Ilmiah

\begin{tabular}{|c|c|c|c|c|c|c|}
\hline Sumber Variasi & $\begin{array}{c}\text { Jumlah } \\
\text { Kuadrat }\end{array}$ & Df & $\begin{array}{c}\text { Rata-Rata } \\
\text { Kuadrat }\end{array}$ & $\mathbf{F}$ & Sig & $\begin{array}{c}\text { Partial Eta } \\
\text { Squared }\end{array}$ \\
\hline Corrected Model & $1478,021^{\mathrm{a}}$ & 2 & 739,010 & 59,668 & 0,000 & 0,634 \\
\hline Intercept & 585,609 & 1 & 585,609 & 47,282 & 0,000 & 0,407 \\
\hline Pretest & 678,021 & 1 & 678,021 & 54,744 & 0,000 & 0,442 \\
\hline Model & 757,933 & 1 & 757,933 & 61,196 & 0,000 & 0,470 \\
\hline Error & 854,590 & 69 & 12,385 & & & \\
\hline Total & 377022,000 & 72 & & & & \\
\hline Corrected Total & 2332,611 & 71 & & & & \\
\hline
\end{tabular}

Tabel 2 menunjukan hasil analisis ANCOVA. Dari output di atas terlihat bahwa angka signifikansi untuk pretest adalah 0,000. Karena nilai Sig. $<0,05$ maka Ho di tolak. Hal ini ini berarti bahwa tingkat kepercayaan $95 \%$ dapat dikatakan ada hubungan linier antara pretest dengan skor sikap ilmiah yang diperoleh peserta didik. Pernyataan ini mengindikasikan bahwa asumsi ANCOVA telah terpenuhi.

Selanjutnya dilakukan pengujian untuk mengetahui pengaruh model pembelajaran terhadap skor sikap ilmiah yang diperoleh peserta didik. Pengujian ini dilakukan dengan menghilangkan pengaruh pretest dari model. Dari hasil pengolahan terlihat bahwa angka signifikansi untuk model pembelajaran adalah 0,000 . Karena nilai sig. $<0,05$ maka Ho di tolak. Sehingga pada tingkat kepercayaan $95 \%$ dapat disimpulkan ada pengaruh model pembelajaran terhadap nilai sikap ilmiah yang diperoleh peserta didik. Selain itu untuk melihat be- sarnya pengaruh model pembelajaran dengan sikap ilmiah dapat dilihat pada nilai partial eta squared untuk model pembelajaran adalah 0,470 yang berarti bahwa model pembelajaran memiliki pengaruh yang sedang terhadap sikap ilmiah. Sejalan dengan pendapat Cohen's (Farzad, Akbaryan, 2013: 7) "Jika angka ukuran pengaruh berkisar $0,2-0,5$ berarti memiliki ukuran pengaruh yang sedang".

Untuk mengetahui pengaruh pretest dan perbedaan model problem based learning terhadap nilai sikap ilmiah yang diperoleh secara simultan dapat dilihat dari angka signifikansi pada bagian Corrected model. Terlihat bahwa angka signifikansi jauh dibawah 0,05 maka Ho di tolak. Sehingga pada tingkat kepercayaan $95 \%$ dapat disimpulkan bahwa pretest dan model pembelajaran berpengaruh terhadap nilai sikap ilmiah yang diperoleh peserta didik

Tabel 3. Ringkasan Hasil Uji ANCOVA Hasil Belajar

\begin{tabular}{lcccccc}
\hline \multicolumn{1}{c}{ Sumber Variasi } & $\begin{array}{c}\text { Jumlah } \\
\text { Kuadrat }\end{array}$ & Df & $\begin{array}{c}\text { Rata-Rata } \\
\text { Kuadrat }\end{array}$ & F & Sig & $\begin{array}{c}\text { Partial Eta } \\
\text { Squared }\end{array}$ \\
\hline Cottected Model & $659,512^{\mathrm{a}}$ & 2 & 347,756 & 74,410 & 0,000 & 0,683 \\
Intercept & 557,741 & 1 & 557,741 & 119,340 & 0,000 & 0,634 \\
Pretest & 134,387 & 1 & 134,387 & 28,755 & 0,000 & 0,294 \\
Model & 159,587 & 1 & 159,587 & 34,147 & 0,000 & 0,331 \\
Error & 322,474 & 69 & 4,674 & & & \\
Total & 37423,000 & 72 & & & & \\
Corrected Total & 1017,986 & 71 & & & & \\
R Squared =0,683 (Adjusted R Squared $=0,674)$ & & & & & \\
\hline
\end{tabular}


Tabel 3 menunjukan hasil analisis ANCOVA. Dari output di atas terlihat bahwa angka signifikansi untuk pretest adalah 0,000. Karena nilai Sig. $<0,05$ maka Ho di tolak. Hal ini ini berarti bahwa tingkat kepercayaan $95 \%$ dapat dikatakan ada hubungan linier antara pretest dengan nilai hasil belajar yang diperoleh peserta didik. Pernyataan ini mengindikasikan bahwa asumsi ANCOVA telah terpenuhi.

Selanjutnya dilakukan pengujian untuk mengetahui pengaruh model pembelajaran terhadap nilai hasil belajar yang diperoleh peserta didik. Pengujian ini dilakukan dengan menghilangkan pengaruh pretest dari model. Dari hasil pengolahan terlihat bahwa angka signifikansi untuk model pembelajaran adalah 0,000. Karena nilai sig. <0,05 maka Ho di tolak. Sehingga pada tingkat kepercayaan 95\% dapat disimpulkan ada pengaruh model pembelajaran terhadap nilai hasil belajar yang diperoleh peserta didik. Selain itu untuk melihat besarnya pengaruh model pembelajaran dengan hasil belajar dapat dilihat pada nilai partial eta squared yaitu untuk model pembelajaran adalah 0,331 yang berarti bahwa model pembelajaran memiliki pengaruh yang sedang terhadap hasil belajar. Sejalan dengan pendapat Cohen's (Farzad, Akbaryan, 2013: 7) "Jika angka ukuran pengaruh berkisar 0,2 - 0,5 berarti memiliki ukuran pengaruh yang sedang".

Untuk mengetahui pengaruh pretest dan perbedaan model problem based learning terhadap nilai hasil belajar yang diperoleh secara simultan dapat dilihat dari angka sigifikansi pada bagian Corrected model. Terlihat bahwa angka signifikansi jauh dibawah 0,05 maka Ho di tolak. Sehingga pada tingkat kepercayaan 95\% dapat disimpulkan bahwa pretest dan model pembelajaran berpengaruh terhadap nilai hasil belajar yang diperoleh peserta didik.

\section{PEMBAHASAN}

Berdasarkan penelitian yang telah penulis lakukan di kelas eksperimen yang proses pembelajarannya menggunakan model pembelajaran problem based learning, setelah di uji dengan ANCOVA, untuk model di dapatkan nilai signifikansi 0,000 sehingga kesimpulan hipotesis yang di dapat adalah tolak Ho, karena hasil nilai signifikansi kurang dari 0,05 .

\section{a. Sikap Ilmiah}

Dimensi sikap ilmiah peserta didik yang di ukur terdiri dari 6 dimensi sikap, yaitu jujur, ingin tahu, terbuka, skeptis, kerja sama dan kritis. Skor maksimum yang diperoleh pada setiap pernyataan adalah 5 dan diperoleh hasil skor yang berbeda pada setiap dimensi sikap ilmiah. Adapun skor pretest, posttest dan $N$-gain setiap dimensi sika ilmiah di kelas eksperimen dapat dilihat pada Gambar 1.

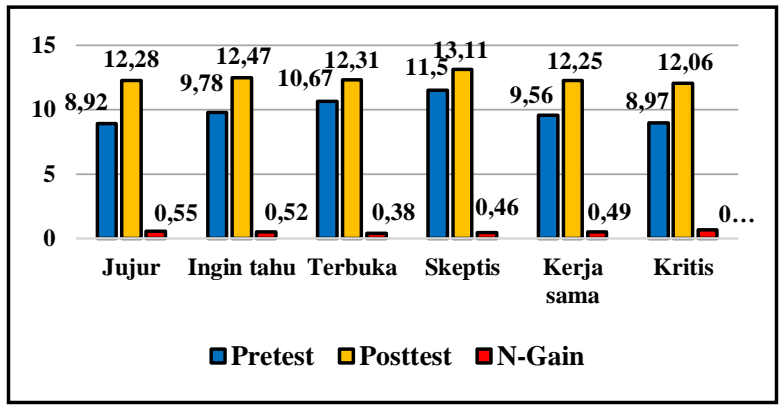

Gambar 1. Diagram Skor Rata-rata Sikap Ilmiah Peserta Didik dalam Setiap Dimensi Sikap Ilmiah di Kelas Eksperimen

Gambar 1 menunjukan bahwa nilai $N$-gain tertinggi pada kelas eksperimen berada pada dimensi sikap ilmiah kritis yaitu sebesar 0,68 , hal tersebut menunjukan bahwa pada saat proses pembelajaran peserta didik diarahkan untuk berfikir kritis saat menyelesaikan permasalahan-permasalahan yang bersifat i'll structure yang disajikan oleh guru yang berkaitan dengan materi psikotropika. Hal ini sesuai dengan pendapat Utomo, Dwiyono Hari, et.al. (2018:45) yang menjelaskan bahwa dalam model problem based learning peserta didik dituntut untuk menemukan masalah dan menggunakan berbagai sumber dalam proses penyelesaian masalah, selain itu dalam proses kegiatan penyelidikan peserta didik akan berlatih berpikir secara ilmiah sesuai prosedur penyelidikan sehingga nantinya kemampuan peserta didik menjadi lebih baik dalam menganalisis suatu permasalahan, kemampuan yang baik dalam menganalisis secara langsung akan mampu meningkatkan sikap kritis peserta didik.

Sedangkan nilai N-gain terendah di kelas eksperimen yaitu terdapat pada dimensi sikap ilmiah terbuka yaitu sebesar 0,38 . Hal ini dikarenakan pada proses kegiatan pembelajaran terutama dalam kegiatan diskusi peserta didik masih belum menyeluruh dapat menerima tanggapan dan saran dari peserta didik lainnya. 
Selanjutnya untuk perolehan skor pretest, posttest dan $\mathrm{N}$-gain setiap dimensi sika ilmiah di kelas kontrol dapat dilihat pada Gambar 2.

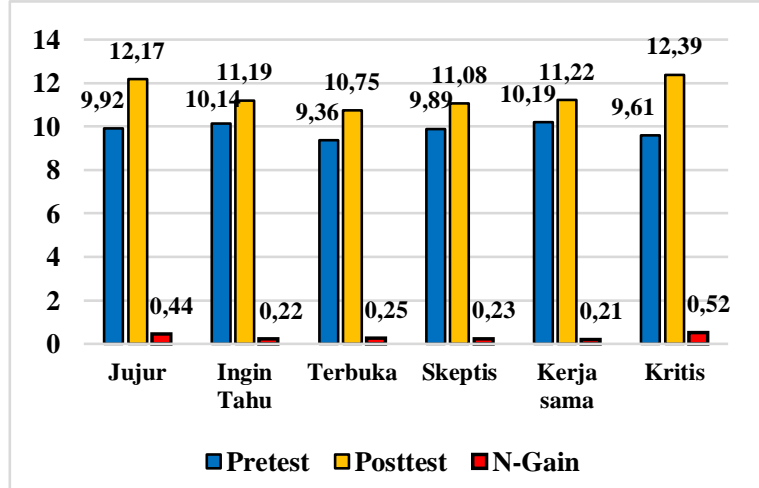

Gambar 2. Diagram Skor Rata-rata Sikap Ilmiah Peserta Didik dalam Setiap Dimensi Sikap Ilmiah di Kelas Kontrol

Gambar 2 menunjukan bahwa nilai N-gain tertinggi pada kelas kontrol berada pada dimensi sikap ilmiah kritis yaitu sebesar 0,52 , hal tersebut menunjukan bahwa pada saat proses pembelajaran peserta didik dituntut untuk aktif mencari atau menemukan sendiri permasalahannya sehingga memacu peserta didik untuk kritis. Hal ini sesuai dengan pendapat Thurman (Wardono dan Nafisa, Dian, 2019:855) menjelaskan bahwa "aspek berpikir kritis melibatkan tahap identifikasi dan analisis sumber informasi untuk kredibilitas, menunjukan pengetahuan sebelumnya dan menyimpulkan kesimpulan, dimana tahap-tahap tersebut terdapat dalam tahap model pembelajaran discovery learning".

Sedangkan nilai $\mathrm{N}$-gain terendah di kelas kontrol yaitu terdapat pada dimensi sikap ilmiah kerja sama yaitu sebesar 0,21 . Hal ini dikarenakan pada proses kegiatan pembelajaran, kelompok kecil yang terdiri dari 6 orang peserta didik dengan kemampuan yang heterogen belum mampu menumbuhkan kesadaran dalam beraktifitas dan bekerja sama secara terstruktur dan interaktif dalam kegiatan kerja ilmiah.

\section{b. Hasil belajar}

Indikator hasil belajar peserta didik yang di ukur terdiri dari 5 jenjang proses kognitif, yaitu mengingat $(\mathrm{C} 1)$, memahami $(\mathrm{C} 2)$, mengaplikasikan (C3), menganalisis (C4) dan mengevalusi (C5). Adapun perolehan skor pretest, posttest dan $\mathrm{N}$-gain pada setiap indikator hasil belajar peserta didik di kelas eksperimen dapat dili-hat pada Gambar 3.

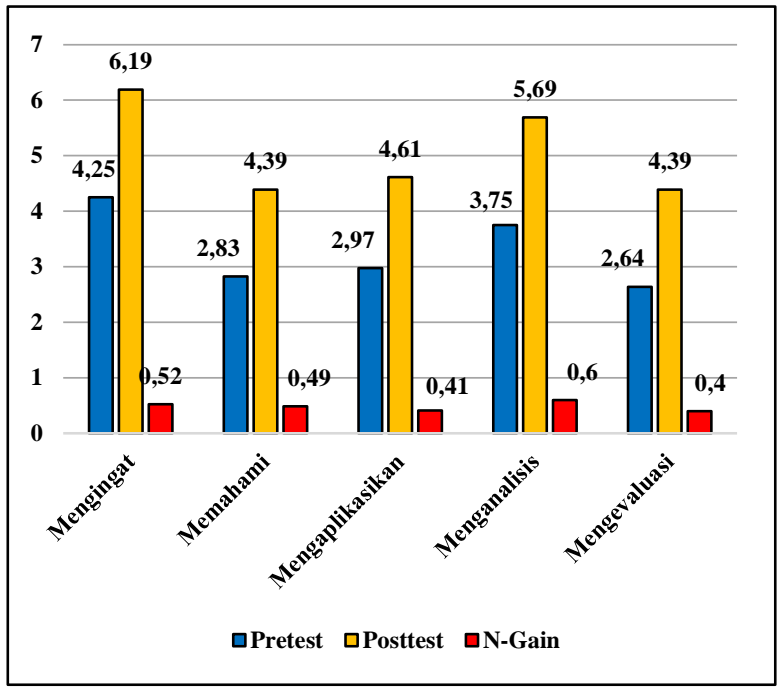

Gambar 3. Diagram Skor Rata-rata Hasil Belajar Peserta Didik dalam Setiap Indikator di Kelas Eksperimen

Gambar 3 menunjukan nilai $N$-gain tertinggi pada kelas eksperimen berada pada indikator menganalisis (C4) yaitu sebesar 0,60, hal tersebut menunjukan bahwa pada saat proses pembelajaran peserta didik diarahkan untuk dapat menganalisis permasalahan yang terdapat pada sub materi psikotropika serta peserta didik di arahkan untuk bisa memecahkan masalah dengan menjawab persoalan sesuai dengan sudut pandang ilmiahnya. Hal ini sesuai dengan pendapat Muslim, Ikhwanul et.al., (2015:38) yang menjelaskan bahwa model pembelajaran problem based learning dapat memberikan kesempatan kepada peserta didik untuk bereksplorasi dalam mengumpulkan dan menganalisis data secara lengkap untuk memecahkan masalah yang dihadapi, sehingga peserta didik mampu untuk berpikir analis dalam menemukan alternatif pemecahan masalah.

Sedangkan nilai N-gain terendah di kelas eksperimen yaitu terdapat pada indikator hasil belajar mengevaluasi (C5) yaitu sebesar 0,40. Hal ini dikarenakan pada proses kegiatan pembelajaran kemampuan peserta didik dalam kegiatan mengevaluasi permasalahan secara detail yang ada pada kehidupan sehari-hari terutama pada sub materi psikotropika masih dikategorikan kurang, karena indikator mengevaluasi (C5) termasuk ke dalam 
HOTS sehingga membutuhkan pembiasaan dengan latihan soal terus-menerus.

Selanjutnya untuk perolehan skor pretest, posttest dan $\mathrm{N}$-gain setiap indikator hasil belajar di kelas kontrol dapat dilihat pada Gambar 4.

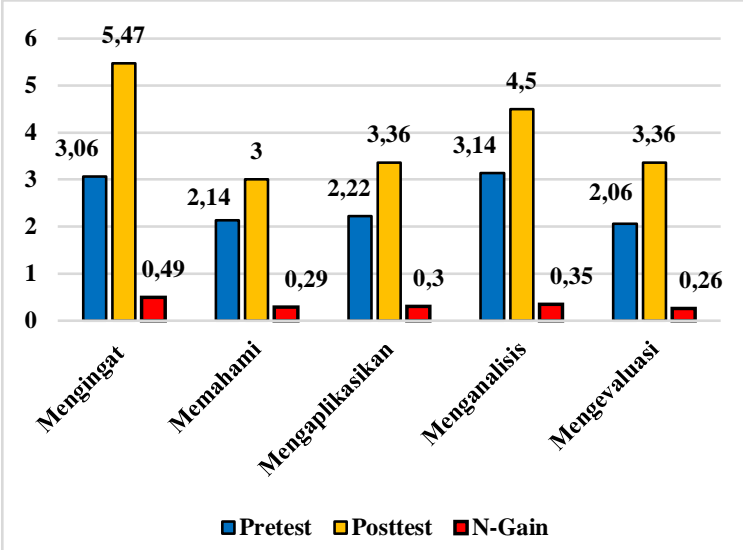

Gambar 4. Diagram Skor Rata-rata Hasil Belajar Peserta Didik dalam Setiap Indikator di Kelas Kontrol

Gambar 4 menunjukan nilai $\mathrm{N}$-gain tertinggi pada kelas eksperimen berada pada indikator mengingat $(\mathrm{C} 1)$ yaitu sebesar 0,49 , hal tersebut menunjukan bahwa pada saat proses pembelajaran guru memberi peluang kepada peserta didik untuk mencari dan menemukan konsep terhadap materi yang dipelajari, sehingga materi yang diperoleh peserta didik akan tertanam dalam ingatan peserta didik dan dapat meningkatkan penguasaan konsep peserta didik.

Sedangkan nilai $\mathrm{N}$-gain terendah di kelas eksperimen yaitu terdapat pada indikator hasil belajar mengevaluasi (C5) yaitu sebesar 0,40. Hal ini dikarenakan pada proses kegiatan pembelajaran kemampuan peserta didik dalam kegiatan mengevaluasi permasalahan pada sub materi psikotropika masih dikategorikan kurang.

\section{IV.KESIMPULAN DAN SARAN}

\section{Kesimpulan}

Berdasarkan hasil analisis data dan pengujian hipotesis, maka diperoleh simpulan yaitu terdapat pengaruh model pembelajaran problem based learning terhadap sikap ilmiah dan hasil belajar peserta didik pada sub materi psikotropika di kelas XI MIPA SMA Negeri 7 Tasikmalaya Tahun Ajaran 2018/2019. Model pembelajaran memiliki pe- ngaruh sebesar 0,470 terhadap sikap ilmiah yang berarti bahwa model pembelajaran problem based learning memiliki pengaruh yang sedang dalam meningkatkan sikap ilmiah peserta didik kelas XI MIPA SMA Negeri 7 Tasikmalaya. Selanjutnya, model pembelajaran problem based learning memiliki pengaruh sebesar 0,331 terhadap hasil belajar yang berarti bahwa model pembelajaran memiliki pengaruh yang sedang dalam meningkatkan hasil belajar peserta didik kelas XI MIPA SMA Negeri 7 Tasikmalaya.

2. Saran

a. Diperlukan persiapan yang matang dalam melaksanakan pembelajaran, khususnya pembelajaran dengan menggunakan model pembelajaran problem based learning, sehingga dalam pelaksanaanya guru dan peserta didik dapat memaksimalkan langkah-langkah pembelajaran untuk mencapai tujuan pembelajaran sesuai dengan yang diharapkan.

b. Untuk penelitian selanjutnya, diharapkan mampu menerapkan model pembelajaran problem based learning terhadap sikap ilmiah dan hasil belajar peserta didik pada materi lain.

\section{DAFTAR PUSTAKA}

Anwar, Herson. (2009). Penilaian Sikap Ilmiah dalam Pembelajaran Sains. 8(2). Mei. Jurnal Pelangi Ilmu.

Asnaeni, L.1., dan Atmojo, I.R.W. (2017). Penerapan Model Pembelajaran Problem Based Learning (PBL) untuk Meningkatkan Sikap Ilmiah pada Pembelajaran IPA Siwa Sekolah dasar. Jurnal Didaktika Dwija Indria (SOLO), 5(5).

Farzad, Akbaryan. (2013). Effect Size. University of Alberta, Canada.

Hmelo-Silver, C.E dan Barrows, H.S. (2006). Goals and Stategies of a Problem-based Learning Facilitator. Interdisciplinary Journal of Problem-based Learning, 1(1).

Muslim, I., Halim, A., dan Safitri, R. (2015). Penerapan Model Pembelajaran PBL untuk Meningkatkan Penguasaan Konsep dan Keterampilan Berpikir Kritis Siswa pada Konsep Elastisitas dan hukum Hooke di SMA Negeri Unggul Harapan Persada. Jurnal Pendidikan Sains Indonesia, 3(2), $35-50$. 
Nafisa, Dian dan Wardono. (2019, Februari). Model Pembelajaran Discovery Learning Berbantuan Multimedia untuk Meningkatkan Kemampuan Berpikir Kritis Siswa. In Prisma Prosiding Seminar Nasional Matematika (Vol.2, pp. 854-961).

Nadjamuddin, Lukman dan Ibrahim, Anna Sylvia. (2017). Pengaruh Model Pembelajaran
Problem Based Learning terhadap Hasil Belajar Mata Pelajaran Ekonomi pada Siswa SMA 1 Palu. Katalogis, 5(4).

Utomo, Dwiyono Hari dan Herzon, Budijanto. (2018). Pengaruh Model Problem Based Learning terhadap Keterampilan Berpikir Kritis. Jurnal Pendidikan: Teori, Penelitian dan Pengenbangan, 3.(1), 42-46. 